\title{
PENERAPAN PENDEKATAN PEMBELAJARAN KOOPERATIF TIPE MAKE A MATCH PADA MATA PELAJARAN DASAR PENGENDALIAN MUTU HASIL PERTANIAN UNTUK MENINGKATKAN HASIL BELAJAR SISWA KELAS X SMK NEGERI 3 TAKALAR
}

\author{
Risma Muspitasari1), Andi Muh. Irfan 2), Purnamawati2) \\ ${ }^{1}$ Alumni Program Studi Pendidikan Teknologi Pertanian \\ ${ }^{2}$ dan ${ }^{3}$ Dosen PTP FT UNM
}

\begin{abstract}
This research is a Classroom Action Research, which aims to improve the students' learning results of class X TPHP SMK Negeri 3 Takalar with the implementation of cooperative learning Make A Match on the lesson of basic quality control of agricultural products. Subjects of this study consisted of 39 students of class X TPHP. The data collected through observation and tests each end of the cycle in accordance with the taught material. Research procedure included the step of: (a) planning, (b) implementation, (c) observation, and (d) reflection. Data were analyzed by using quantitative data. The results of the research show that the application of cooperative learning approach type Make A Match can improve students' learning result. This was seen in the pre-test, the first and the second cycle of students' learning result had increased.
\end{abstract}

Keywords : Class Action, Make A Match, Learning Result, Quantitative.

\section{PENDAHULUAN}

Kompetensi suatu Negara dalam persaingan global lebih ditentukan oleh sumber daya manusia yang berkualitas. Sumber daya manusia yang berkualitas sangat tergantung pada sistem pendidikan formal, informal, dan non formal yang dilaksanakan dan dikembangkan oleh Negara tersebut. Pemerintah Indonesia telah berupaya untuk meningkatkan kualitas pendidikan formal, baik melalui peningkatan kualitas guru, perbaikan sarana dan prasarana sekolah, maupun peningkatan hasil belajar peserta didik melaluipeningkatan standar ketuntasan belajar.

Aturan dalam UU RI No 20 Tahun 2003 pasal 1 menjelaskan "pendidikan adalah usaha sadar dan terencana untuk mewujudkan suasana belajar dan proses pembelajaran agar peserta didik secara aktif mengembangkan potensi dirinya untuk memiliki kekuatan spiritual keagamaan, pengendalian diri, kepribadian, kecerdasan, akhlak mulia, serta keterampilan yang diperlukan dirinya, masyarakat, bangsa dan negara". Lebih lanjut dalam pasal 3 diamanatkan mengenai fungsi dan tujuan pendidikan, bahwa pendidikan nasional berfungsi mengembangkan kemampuan dan membentuk watak serta peradaban bangsa yang bermartabat dalam rangka mencerdaskan kehidupan bangsa, bertujuan untuk berkembangnya potensi peserta didik agar menjadi manusia yang beriman dan bertaqwa kepada Tuhan Yang Maha Esa, berakhlak mulia, sehat, berilmu, cakap, kreatif, mandiri, danmenjadi warga negara yang demokratis serta bertanggung jawab. Pendidikan merupakan faktor utama yang menentukan kualitas suatu bangsa. 
Pendidikan bukanlah sesuatu yang bersifat statis melainkan sesuatu yang bersifat dinamis sehingga selalu menuntut adanya suatu perbaikan yang bersifat terus menerus. Peran pendidikan yang sangat penting untuk menciptakan kehidupan yang cerdas, damai, terbuka dan demokratis. Oleh karena itu, pembaharuan pendidikan terus selalu dilakukan untuk meningkatkan kualitas pendidikan nasional. Berbagai upaya yang telah di lakukan antara lain pembaruan kurikulum, peningkatan kualitas guru, penyediaan perpustakaan dan laboratorium, penataan manajemen pendidikan serta penerapan produk teknologi.

Sekolah Menengah Kejuruan (SMK) adalah sekolah yang bertujuan untuk mempersiapkan peserta didiknya untuk dapat bekerja pada bidang tertentu. Dalam mencapai tujuan tersebut, peserta didik berinteraksi dengan lingkungan belajar yang diatur guru melalui proses pembelajaran. Sistem pembelajaran yang dilaksanakan di SMK, peserta didik dituntut memiliki skill yang sesuai dengan bidang keahlian tertentu sesuai dengan minat dan bakat yang akan menjadi dasar pengembangan ilmu.

Hasil observasi yang dilakukan pada bulan Januari 2015 tentang pembelajaran Dasar Pengendalian Mutu Hasil Pertanian di SMK Negeri 3 Takalar kelas $X$ Program Studi Teknologi Pengolahan Hasil Pertanian (TPHP), saat berlangsungnya proses pembelajaran Dasar Pengendalian Mutu Hasil Pertanian di kelas interaksi aktif positif antara peserta didik dengan guru, tetapi sebaliknyainteraksi antarpeserta didik dengan peserta didik jarang terjadi. Peserta didik terlihat kurang terampil menjawab pertanyaan ataupun bertanya tentang materi yang diajarkan.Peserta didik tidak antusias menerima pembelajaran, hal ini terlihat masih banyaknya peserta didik yang berinteraksi dengan peserta didik lainnya yang membahas diluar materi yang diajarkan, rata-rata nilai hasil belajar peserta didik kelas $X$ pada mata pelajaran Dasar Pengendalian Mutu Hasil Pertanian yang berjumlah keseluruhan 39 peserta didik, ada 16 peserta didik diantaranya telah memenuhi Kriteria Ketuntasan Minimal (KKM) yang telah dipersyaratkan yaitu 70 , sedangkan 23 peserta didik lainnya belum memenuhi Kriteria Ketuntasan Minimal (KKM)) yang telah dipersyaratkan yaitu 70 .

Hasil pengamatan menunjukkan banyak faktor yang dapat menyebabkan hal tersebut terjadi, salah satu diantaranya adalah pembelajaran terpusat pada guru. Guru dominan menggunakan metode ceramah dan menggunakan metode Terangkan Catat Latihan (TCL) di depan kelas tanpa ada keterlibatan peserta didik secara langsung.

Hal ini Mengakibatkan pengetahuan yang didapat peserta didik berasal dari guru bukan dibangun sendiri secara bertahap oleh peserta didik atas dasar pemahaman sendiri.Kemampuan guru dalam menyampaikan materi kurang memadai sehingga pembelajaran terasa kurang menarik dan cenderung membosankan. Berdasarkan hasil wawancara dengan guru, diperoleh informasi bahwa rendahnya hasil belajar mata pelajaran Dasar Pengendalian Mutu Hasil Pertanian peserta didik juga disebabkan materi yang dipelajari bersifat tidak kompleks, sehingga guru merasa kesulitan mengajar dan peserta didik kesulitan memahami materi. Untuk mengatasi masalah tersebut di atas, perlu diupayakan suatu pendekatan 
pembelajaranyang dapat digunakanagar peserta didik lebih aktif dalam proses pembelajaran sehingga hasil belajar peserta didik meningkat. Salah satu cara yang dapat ditempuh adalah dengan menerapkan pendekatan pembelajaran kooperatif tipe make a match. Komalasari (2011) menjabarkan bahwa, "Pembelajaran kooperatif (cooperative learning) merupakan strategi pembelajaran melalui kelompok kecil peserta didik yang saling bekerja sama dalam memaksimalkan kondisi belajar untuk mencapai tujuan belajar".

Penggunaan model pembelajaran kooperatif tipe make a match pada Mata Pelajaran Dasar Pengendalian Mutu Hasil Pertanian ini akan membantu dan mempermudah proses pembelajaran untuk peserta didik maupun guru. Peserta didik dapat belajar lebih dahulu dengan melihat dan menyerap materi belajar dengan lebih utuh. Dengan demikian, guru tidak harus menjelaskan materi secara berulang-ulang sehingga proses pembelajaran dapat berlangsung lebih menarik, lebih efektif dan efisien. Dengan petimbangan di atas, perlu diadakan penelitian tentang peningkatan kualitas pembelajaran pada Mata Pelajaran Dasar Pengendalian Mutu Hasil Pertanian. Berdasarkan fakta tersebut peneliti tertarik melakukan penelitian dengan menggunakan metode dengan judul "Penerapan Pendekatan Pembelajaran Kooperatif Tipe Make A Match pada Mata Pelajaran Dasar Pengendalian Mutu Hasil Pertanian Untuk Meningkatkan Hasil Belajar Peserta didik Kelas X SMK Negeri 3 Takalar". Tujuan penelitian yang ingin dicapai adalah untuk mengetahui peningkatan hasil belajar pada Mata Pelajaran Dasar Pengendalian Mutu Hasil Pertanian peserta didik kelas $X$ SMKNegeri 3 Takalar melalui penerapan model pembelajaran kooperatif tipe make a match.

\section{METODE PENELITIAN}

Penelitian yang dilakukan merupakan Penelitian Tindakan Kelas (PTK) dengan tahap pelaksanaan meliputi: perencanaan, pelaksanaan tindakan, pengamatan, dan refleksi. Penelitian ini dilaksanakan dalam siklus, setiap siklus dilaksanaan 3 kali pertemuan, model siklus dapat dilihat pada Gambar 1.

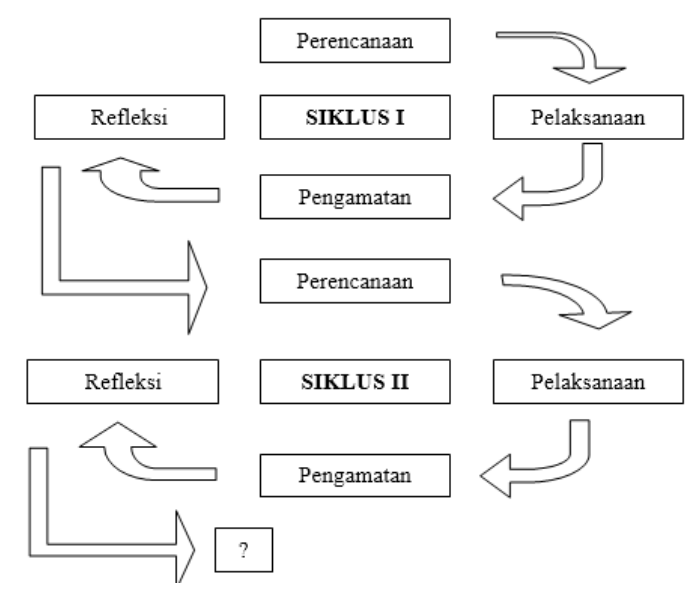

\section{Gambar 1}

Alur Pelaksanaan Tindakan Kelas (Arikunto, dkk. 2006)
Sebelum melaksanakan siklus I dan siklus II, terlebih dahulu dilaksanakan tes awal (pre Test) sebagai pembanding untuk mengetahui hasil belajar peserta didik sebelum diterapkan metode pembelajaran dansebagai data acuan serta perbandingan sebelum melakukan post test pada siklus I.Pelaksanaan penelitian ini direncanakan dalam dua siklus kegiatan, dengan rincian sebagai berikut:
1. Siklus I dilaksanakan sebanyak 4 kali pertemuan


2. Siklus II dilaksanakan sebanyak 3 kali pertemuan

Tiap siklus terdiri dari beberapa tahap kegiatan sesuai hakikat penelitian yaitu perencanaan, pelaksanaan tindakan, observasi, dan refleksi. Kegiatan pada siklus II merupakan pengulangan dan perbaikan terhadap kelemahan pada siklus I.

\section{HASIL DAN PEMBAHASAN}

Hasil penelitian ini dibuat berdasarkan data yang diperoleh dari kegiatan penelitian tentang peningkatan hasil belajar peserta didik pada mata pelajaran Dasar Pengendalian Mutu Hasil Pertanian melalui model pembelajaran kooperatif tipe Make $A$ Match yang dilaksanakan di SMK Negeri 3 Takalar. Pelaksanaan penelitian ini dilakukan dengan 2 siklus. Analisis yang dilakukan meliputi hasil tes awal, tes akhir siklus I dan siklus II, serta data tambahan berupa perubahan sikap peserta didik yang diambil dari hasil pengamatan terhadap peserta didik selama penelitian berlangsung.

\section{Tabel 1}

Distribusi Ketuntasan Belajar Peserta didik Kelas X TPHP SMK Negeri 3

Takalar pada Siklus I

Sumber: Hasil analisis data penelitian

\begin{tabular}{cccc}
\hline Skor & Frekuensi & $\begin{array}{c}\text { Persentase } \\
\text { (\%) }\end{array}$ & Kategori \\
\hline $0-69$ & 11 & 28,95 & Tidak \\
$70-100$ & 27 & 71,05 & tuntas \\
& & & Tuntas \\
\hline Jumlah & 38 & 100 & \\
\hline
\end{tabular}

2015

Hasil penelitian menunjukkan persentase ketuntasan belajar peserta didik adalah $71,05 \%$ atau ada 27 peserta didik dari 38 peserta didik sudah tuntas belajar, sedangkan $28,95 \%$ atau 11 peserta didik dari 21 peserta didik tidak tuntas belajar. Hal ini berarti bahwa terdapat 16 peserta didik yang perlu perbaikan karena belum mencapai kriteria ketuntasan belajar.

Hasil tersebut menunjukkan bahwa pada siklus I secara klasikal belum tuntas belajar, karena peserta didik yang memperoleh nilai $\geq 70$ hanya sebesar $71,05 \%$ lebih kecil dari persentase ketuntasan yang dikehendaki yaitu sebesar $85 \%$. Hal ini disebabkan karena masih banyak aktivitas peserta didik yang rendah, sehingga kurangnya pemahaman yang peserta didik dapatkan selama pembelajaran. Kemudian salah satu faktor penyebab rendahnya hasil belajar pada mata pelajaran penerapan dasar pengendalian mutu hasil pertanian adalah model pembelajaran kooperatif tipe make a match yang masih membutuhkan sesuatu yang menarik agar dapat menumbuhkan rasa semangat peserta didik untuk belajar. Penelitian ini perlu dilanjutkan pada siklus berikutnya karena berdasarkan tujuan yang ingin dicapai peningkatan hasil belajar belum tuntas.

Hasil analisis siklus II (Tabel 2) diperoleh persentase ketuntasan belajar peserta didik adalah $86,49 \%$ atau ada 32 peserta didik dari 37 jumlah peserta didik sudah dinyatakan tuntas belajar, sedangkan $13,51 \%$ atau 5 peserta didik dari 37 jumlah peserta didik dinyatakan tidak tuntas belajar. Hasil tersebut menunjukkan bahwa pada tes akhir siklus II (post-test) secara klasikan sudah dinyatakan tuntas belajar, karena klasikal ketuntasan yang dikehendaki $85 \%$. Analisis refleksi siklus II ini ada beberapa hal yang menjadi kendala dalam kegiatan pembelajaran diantaranya adalah tingkat kehadiran peserta didik 
yang masih sangat kurang. Hal keaktifan dalam kelompok permasalahannya sudah dapat teratasi meskipun penigkatannya tidak terlalu signifikan. Peserta didik yang melakukan kegiatan lain cenderung mulai berkurang. Hal ini disebabkan karena peserta didik tersebut ingin mendapatkan nilai dan keingin tahuan tentang materi.

Tabel 2

Distribusi KetuntasanPeserta didik Kelas X TPHP SMK Negeri 3 Takalarpada Siklus II

\begin{tabular}{cccc}
\hline Skor & Frekuensi & $\begin{array}{c}\text { Persentase } \\
(\mathbf{\% )}\end{array}$ & Kategori \\
\hline $0-69$ & 5 & 13,51 & Tidak \\
$70-100$ & 32 & 86,49 & $\begin{array}{c}\text { tuntas } \\
\text { Tuntas }\end{array}$ \\
& & & \\
\hline Jumlah & 37 & 100 & \\
\hline
\end{tabular}

Sumber: Hasil analisis data penelitian 2015

Peningkatan peserta didik baik dalam proses maupun hasil belajar dapat dilihat pada hasil analisis lembar observasi peserta didik dan hasil tes akhir siklus II sudah berpedoman pada hasil refleksi siklus I, sehingga apa yang telah direncanakan pada siklus II dapat terlaksana dengan optimal. Pencapaian indikator keberhasilan penelitian, menunjukkan bahwa penelitian ini dapat diakhiri dengan 2 siklus atau dengan kata lain penelitian ini tidak dilanjutkan lagi ke siklus III

Model pembelajaran kooperatif tipe make a match pada mata pelajaran dasar pengendalian mutu hasil pertanian peserta didik kelas X SMK Negeri 3 Takalar secara umum dapat meningkatkan hasil belajar peserta didik dari siklus I ke siklus II. Berdasarkan data hasil tes belajar peserta didik yang mengalami peningkatan dari pertemuan pertama dan ke pertemuan selanjutnya.

Hasil observasi yang dilakukan selama dua siklus dengan menerapkan metode pembelajaran kooperatif tipe make a matchmemberikan banyak perubahan kepada peserta didik, diantaranya:

1. Peserta didik lebih terbuka untuk berpendapat, menyapa, dan berkomunikasi dengan peserta didik yang lainnya.

2. Peserta didik tidak tertekan pada saat proses pembelajaran dengan model pembelajaran kooperatif tipe make a match

3. Peserta didik lebih akrab dengan peserta didik yang lain.

4. Peserta didik merasa senang dengan metode yang diterapkan

Kendala yang terjadi di awalproses pembelajaran antara lain masih banyak peserta didik yang tidak memiliki keberanian untuk bertanya, serta masih ada peserta didik yang kurang aktif dalam kegiatan kelompok. Tetapi hal ini tidak berlangsung lama karena diakhir siklus I sudah terjadi perubahan ke arah yang lebih baik, peserta didik sudah mulai berani untuk bertanya.

Peserta didik yang aktif mengalami peningkatanselama kegiatan pembelajaran siklus II, karena semua peserta didik aktif dalam mencari pasangan kartu. Setiap peserta didik memiliki tugas masing-masing dalam mencari pasangan kartu soal dan jawaban, sehingga terjalin kerjasama antar peserta didik dan juga komunikasi antar peserta didik meningkat, dimana terjadi timbal balik antara peserta didik yang melaporkan hasil pasangan mereka kepada guru dan peneliti.Pada siklus I, peserta didik yang melakukan kegiatan 
lain baik dalam proses pemberian materi pelajaran maupun di saat mengerjakan tugas mengalami peningkatan. Hal ini disebabkan peserta didik aktif dalam pencari pasangan kartu soal dan jawaban yang telah diberikan dalam tiap kelompok. Tidak ada waktu bagi peserta didik untuk mengerjakan kegiatan lain selain mencari pasangan kartu soal dan jawaban, dikarenakan target waktu yang telah ditentukan.

Penelitian ini membandingan nilai KKM yang telah ditetapkan oleh sekolah dengan nilai yang telah dicapai peserta didik pada siklus I dan siklus II yaitu nilai hasil belajar pada mata pelajaran dasar pengendalian mutu hasil pertanian peserta didik kelas $X$ SMK Negeri 3 Takalar pada siklus I dan siklus II melalui penerapa model pembelajaran kooperatif tipe make a match dapat dilihat pada Tabel 4.6 siklus I nilai terendah peserta didik yaitu 59,4 dan nilai tertinggi adalah 82,5 dengan rata-rata 71,04 berdasarkan hasil refleki pada siklus I distribusi ketuntasan belajar peserta didik belum memenuhi standar klasikal yaitu $85 \%$ Hasil tersebut dilihat pada Tabel 4.8 dengan jumlah peserta didik 11 persentase 28,95 dan 27 dengan persentase 71,05 . Terlihat masih ada beberapa peserta didik yang belum memenuhi Kriteria Ketuntasan Minimal (KKM) yaitu 70 . Hal ini teradi karena bebrapa fakto diantaranya model pembelajran masih terasa asing bagi sebagian peserta didik, waktu yang dibutuhkan masih belum mencukupi dalam pembelajaran, masih ada beberpa peserta didik yang salah memilih pasangan serta masih ada beberapa peserta didik yang mengaganggu teman yang lain. Oleh karena itu peneliti melakukan perbaikan pada siklus II dengan bercermin pada hasil refleksi siklus I.
Selelah dilakukan perbaikan pada siklus II maka terlihat adanya peningkatan hasil belajar. Nilai terendah peserta didik pada siklus II yaitu 52,8dan nilai tertinggi 89,1 dengan rata-rata 76,79 . Dengan distribusi ketuntasan dimana jumlah peserta didik 32 dengan persentase 86,49 dan peserta didik 5 dengan persentase 13,51. Berdasarkan data nilai tersebut maka terlihat adanya peningkatan hasil belajar peserta didik yang telah memnuhi standar klasikal yaitu $85 \%$.Walaupun terlihat adanya peningkatan pada siklus II setelah dilakukan refleksi dari 37 peserta didik yang mengikuti tes, terdapat 5 orang peserta didik yang termasuk kategori tidak tuntas. Hal ini mungkin saja disebabkan oleh faktor internal dan eksternal dari peserta didik tersebut.

Menurut Slameto (2003), faktorfaktor yang mempengaruhi belajar adalah faktor-faktor internal dan faktor eksternal. Faktor-faktor internal meliputi jasmaniah (kesehatan, cacat tubuh), psikologis (intelegensi, perhatian, minat, bakat, motif, kematangan, kesiapan) dan kelelahan. Faktor-faktor eksternal meliputi keluarga (cara orang tua mendidik, relasi antar anggota keluarga, suasana rumah, keadaan ekonomi keluarga, pengertian orang tua, latar belakang, kebudayaan), sekolah (metode mengajar, kurikulum, relasi guru dengan peserta didik, relasi peserta didik dengan peserta didik, disiplin sekolah, alat pelajaran, waktu sekolah, standar pelajaran di atas ukuran, keadaan gedung, metode belajar, tugas rumah), dan masyarakat (kegiatan peserta didik dalam masyarakat, media massa, teman bergaul, bentuk kehidupan masyarakat).

Menurut Thomas F Staton dalam Haling, (2007) seseorang akan berhasil dalam belajar, kalau pada dirinya ada keinginan untuk belajar. Keinginan atau 
dorongan inilah yang disebut motivasi. Motivasi dalam hal ini meliputi dua hal: 1) mengetahui apa yang akan dipelajari, dan 2) memahami mengapa hal tersebut patut untuk dipelajari. Kedua unsur motivasi inilah sebagai dasar pemulaan yang baik untuk belajar, sebab tanpa motivasi kegiatan belajar sulit untuk berhasil.

Model pembelajaran kooperatif tipe Make A Match, peserta didik akan mengkonstruksi sendiri pengetahuan mereka melalui keterlibatan aktif dalam proses diskusi. Menurut Trianto (2007), peserta didik akan lebih mudah menemukan dan memahami konsepkonsep yang sulit jika mereka saling mendiskusikan masalah tersebut dengan temannya.Sesuai dengan teori tersebut maka dapat dilihat bahwa ketika peserta didik berperan langsung dan aktif pada proses pembelajaran dalam pengalaman sendiri maka peserta didik akan lebih mudah memahami suatu pelajaran karena mencari informasi sendiri sehingga peserta didik langsung mengalami sendiri dan akan memperoleh pengalaman sendiri.

Hasil belajar mereka meningkat setelah melalui pengalaman belajar dalam kurun waktu tertentu yang diukur dengan menggunakan beberapa tes dimana pengalaman belajar yang dilalui berupa beberapa siklus dan beberapa tes yang diberikan oleh guru. Berdasarkan pada indikator keberhasilan. maka hasil belajar peserta didik dari siklus I sampai pada siklus II meningkat dan telah memenuhi indikator keberhasilan yang telah ditetapkan oleh Departemen Pendidikan Nasional.

\section{KESIMPULAN}

Hasil kegiatan yang telah
dilakukan selama dua siklus, dan berdasarkan seluruh pembahasan serta analisis yang telah dilakukan dapat disimpulkan bahwa peningkatan hasil belajar pada Mata Pelajaran Dasar Pengendalian Mutu Hasil Pertanian peserta didik kelas $X$ SMK Negeri 3 Takalar melalui penerapan model pembelajaran kooperatif tipe make a match mengalami peningkatan. Hal tersebut dapat ditunjukkan dari nilai ratarata hasil belajar pada Mata Pelajaran Dasar Pengendalian Mutu Hasil Pertanian pada siklus I ke siklus II, yaitu 71,05 meningkat menjadi 86,49 dengan Kriteria Ketuntasan Minimum (KKM) yaitu 70. Model pembelajaran kooperatif tipe make a matchpada Mata Pelajaran Dasar Pengendalian Mutu Hasil Pertanian dapat memberikan perubahan terhadap keaktifan siswa yang ditandai dengan adanya frekuensi kehadiran siswa yang meningkat, keterlibatan siswa secara aktif dalam proses pembelajaran, semakin banyaknya siswa yang aktif dalam mencari pasangan kartu dan mampu menyelesaikan sesuai dengan waktu yang ditentukan.

\section{DAFTAR PUSTAKA}

Anonim. 2015. Undang Undang Sistem Pendidikan Nasional. www.hukumonline.com diakses pada tanggal 21 februari 2015

Anonim. 2015. Nilai Pelajaran Siswa Kelas X TPHP . SMKN 3 Takalar

Arikunto, Suharsimi. 2006. Dasar-Dasar Evaluasi Pendidikan (Edisi Revisi). Jakarta: Bumi Aksara.

Haling, Abdul; Parumbuan; Pattaufi; Nurhikmah Arsal; Arnidah; dan Faridah Pebrianti. 2007. Belajar dan Pembelajaran. Makassar: Badan Penerbit UNM. 
Risma Muspitasari, Et al / Jurnal Pendidikan Teknologi Pertanian, Vol. 2 (2016) : 97-104

Slameto. 2003. Belajar dan Faktor-faktor yang Mempengaruhinya. Rineka Cipta Jakarta. 